\title{
Influence of main dietary chemical constituents on the in vitro gas and methane production in diets for dairy cows
}

\author{
Laura Maccarana ${ }^{1}$, Mirko Cattani ${ }^{1 *}$, Franco Tagliapietra ${ }^{2}$, Lucia Bailoni ${ }^{1}$ and Stefano Schiavon ${ }^{2}$
}

\begin{abstract}
Background: Modification of chemical composition of diets fed to dairy cows might be a good strategy to reduce methane $\left(\mathrm{CH}_{4}\right)$ production in the rumen. Notable reductions of $\mathrm{CH}_{4}$ production compared to conventional highroughages rations were more frequently observed for very concentrated diets or when fat supplements were used. In these cases, the reduction in the gas emission was mainly a consequence of an overall impairment of rumen function with a reduction of fiber digestibility. These strategies do not always comply with feeding standards used in intensive dairy farms and they are usually not applied owing to the risks of negative health and economic consequences. Thus, the present study evaluated the effects of seven commercial diets with contents of neutral detergent fiber (NDF), protein and lipids ranging 325 to $435 \mathrm{~g} / \mathrm{kg} \mathrm{DM}, 115$ to $194 \mathrm{~g} / \mathrm{kg} \mathrm{DM}$, and 26 to $61 \mathrm{~g} / \mathrm{kg} \mathrm{DM}$, respectively, on in vitro degradability, gas (GP), and $\mathrm{CH}_{4}$ production.

Results: In this experiment, changes in the dietary content of NDF, crude protein (CP) and lipids were always obtained at the expense or in favor of starch. A decreased of the dietary NDF content increased NDF (NDFd) and true DM (TDMd) degradability, and increased $\mathrm{CH}_{4}$ production per $\mathrm{g}$ of incubated $\mathrm{DM}(P<0.001)$, but not that per $\mathrm{g}$ of TDMd. An increase of the dietary CP level did not change in vitro NDFd and TDMd, decreased GP per $g$ of incubated DM $(P<0$. 001), but $\mathrm{CH}_{4}$ production per $\mathrm{g}$ of TDMd was not affected. An increased dietary lipid content reduced NDFd, TDMd, and GP per $\mathrm{g}$ of incubated DM, but it had no consequence on $\mathrm{CH}_{4}$ production per $\mathrm{g}$ of TDMd.

Conclusions: It was concluded that, under commercial conditions, changes in dietary composition would produce small or negligible alterations of $\mathrm{CH}_{4}$ production per unit of TDMd, but greater differences in $\mathrm{GP}$ and $\mathrm{CH}_{4}$ production would be expected when these amounts are expressed per unit of DM intake. The use of TDMd as a standardizing parameter is proposed to account for possible difference in DM intake and productivity.
\end{abstract}

Keywords: Dairy cows, Dietary manipulation, Gas production, In vitro techniques, Methane production

\section{Background}

Mitigation of methane $\left(\mathrm{CH}_{4}\right)$ production from rumen fermentation represents an important target for animal nutritionists, as also this gas is responsible for global warming. Thus, the manipulation of dietary nutrient composition is often proposed as a strategy that farmers may exploit to reduce the proportion of energy lost by animals as eructated gases $\left(\mathrm{CH}_{4}\right)$ and to improve feed and energy efficiency [1]. There is evidence that the amount of $\mathrm{CH}_{4}$ produced in the rumen is influenced by

\footnotetext{
* Correspondence: mirko.cattani@unipd.it

${ }^{1}$ Department of Comparative Biomedicine and Food Science (BCA),

University of Padova, Viale dell'Università 16, 35020 Legnaro (PD), Italy

Full list of author information is available at the end of the article
}

type and content of dietary carbohydrates [2] and lipids [3]. In practice, notable reductions of $\mathrm{CH}_{4}$ production compared to conventional high-roughages rations were more frequently observed for very concentrated diets [4] or when fat supplements [3] were used. In these cases the reduction in the gas emission was mainly a consequence of an overall impairment of rumen function with a reduction of fiber digestibility [5]. Thus, these strategies do not always comply with the feeding standards used in intensive dairy farms and they are usually not applied owing to the risks of negative health and economic consequences [6]. Compared to carbohydrates and lipids, minor effects on rumen gas production and methanogenesis are usually attributed to the crude protein $(\mathrm{CP})$. In this regard, 
[7] observed that $\mathrm{CH}_{4}$ production related to $\mathrm{CP}$ fermentation was lower compared to that due to carbohydrate fermentation. To date, changes in the dietary CP content have been mainly addressed to reduce feeding costs and $\mathrm{N}$ excretion $[8,9]$. However, dietary strategies to reduce $\mathrm{N}$ excretion could also have an impact because $\mathrm{CH}_{4}$ production may decline when dietary $\mathrm{CP}$ is replaced by rumen bypass nutrients, including starch, escaping rumen fermentation [10]. Despite this, little information is currently available on the effects on $\mathrm{CH}_{4}$ production due to changes in dietary CP content.

This in vitro study was aimed at evaluating the extent of alterations of true dry matter degradability (TDMd), total gas (GP) and $\mathrm{CH}_{4}$ productions caused by changes in the proportions of the main feed ingredients and of the dietary constituents (structural and non-structural carbohydrates, CP and lipids) in TMR samples representative of rations commonly used in intensive farms in North Italy.

\section{Methods}

\section{Chemical composition of the diets}

Diets used in this experiment were defined after an analysis of a database containing information about ingredient and chemical composition of the rations used by 90 farms considered to be representative of the dairy farm system in North Italy $[11,12]$.

A corn silage-diet, containing 361, 158, and $33 \mathrm{~g} / \mathrm{kg}$ of NDF, CP, and lipids, respectively, was used as a reference (Table 1). Six other diets were formulated to produce variations in the proportion of some feed ingredients, and hence in content of a given chemical constituent in favor or at the expense of starchy feeds, with respect to the reference diet. Thus, changes in the dietary content of NDF, CP and lipids, were always obtained at the expense or in favor of starch. Two diets with a low (325 g/kg DM) or a high (435 g/kg DM) content of NDF were formulated by replacing, accordingly, roughages (corn silage, alfalfa hay, and ryegrass hay) with corn and barley grains in the form of meal. The diet with the high NDF content did not contain corn silage, taking into consideration dairy farms that are not allowed to use this feed as they produce milk to be processed as Italian Protected Designation of Origin (PDO) ParmigianoReggiano cheese. Other two diets, with a low $(115 \mathrm{~g} / \mathrm{kg}$ $\mathrm{DM}$ ) or a high CP content (194 g/kg DM), were formulated by replacing, accordingly, soybean meal with cereal grains (corn and barley meal). It must be underlined that the upper level of CP tested in this study corresponded to the maximum value found in the considered database of 90 farms. This value is high if compared with ranges in CP contents (118-186 g/kg DM) reported for rations used in dairy farms of North-Italy [12]. Two diets with different ether extract (EE) content were also formulated. A low EE diet (26 g/kg DM) was achieved by excluding the extruded flaxseed (Linoies, Cortal Extrasoy, Cittadella, Italy), present in the reference diet, and increasing the content of corn, barley and soybean meal. The high EE diet (61 g/kg DM) was achieved by including whole soybean seeds, extruded soybean (Soyfull, Cortal Extrasoy, Cittadella, Italy) and extruded flaxseed. All diets were prepared at the laboratory of the University of Padova. For preparation, about $1 \mathrm{~kg}$ of each diet was ground to $1 \mathrm{~mm}$ using a hammer mill (Pullerisette 19, Fritsch $\mathrm{GmbH}$, Laborgeratebau, Germany). For each diet, 23 samples were randomly collected, 20 of which were used for the incubations ( 5 per each of the 4 incubations), whereas the remaining were used for chemical analysis.

Diets were analyzed in triplicate for dry matter (DM: \# 934.01; [13]), nitrogen (\# 976.05; [13]), EE (\# 920.29; [13]), and ash (\# 942.05; [13]). Neutral detergent fibre (NDF), inclusive of residual ash, was determined with $\alpha$-amylase using the Ankom ${ }^{220}$ Fibre Analyzer (Ankom Technology, NY, USA). Acid detergent fibre (ADF), inclusive of residual ash, and sulphuric acid lignin $\left(\operatorname{lignin}_{(\mathrm{sa})}\right)$ were determined sequentially after NDF determination [14]. Starch content was determined after hydrolysis to glucose [13] by liquid chromatography [15]. Gross energy content of diets (MJ/ $\mathrm{kg} \mathrm{DM}$ ) was determined in duplicate by a bomb calorimeter method [16].

\section{Incubation}

The 7 diets were incubated in 4 repeated incubation runs, conducted in 4 successive wk. Two incubations were stopped at $24 \mathrm{~h}$, whereas the other two were stopped after $48 \mathrm{~h}$. The incubation times of 24 and $48 \mathrm{~h}$ were chosen as they are, respectively, the reference times for measuring in vitro GP [17] and in vitro degradability of NDF [18]. In each of the four incubation runs, we tested 7 diets $\times 5$ replications, plus 5 blanks (bottles containing only the buffered rumen fluid; 5 blanks/run), for a total of 160 bottles incubated. A commercial GP apparatus (Ankom ${ }^{\text {RF }}$ Gas Production System, Ankom Technology ${ }^{\oplus}$ NY, USA) was used, consisting of 40 bottles equipped with pressure sensors (pressure range: from - 69 to $3,447 \mathrm{kPa}$; resolution: $0.27 \mathrm{kPa}$; accuracy: \pm $0.1 \%$ of measured value) and wireless connected to a computer. Each bottle $(317 \mathrm{~mL})$ was filled with $1.000 \pm$ $0.0010 \mathrm{~g}$ of diet, $100 \mathrm{~mL}$ of a buffer solution, and $50 \mathrm{~mL}$ of rumen fluid (headspace volume $=167 \mathrm{~mL}$ ), keeping the headspace of bottles flushed with $\mathrm{CO}_{2}$.

The buffer solution was prepared according to [17], heated in a water bath at $39 \pm 0.4{ }^{\circ} \mathrm{C}$ and purged continuously with $\mathrm{CO}_{2}$ for $30 \mathrm{~min}$, to maintain anaerobic conditions. Rumen fluid was collected by an esophageal probe, as described by [19], 2 h before morning feeding from 3 dry Holstein-Friesian cows housed at the experimental farm of the University of Padova (Italy) and fed hay ad libitum and $2.5 \mathrm{~kg} / \mathrm{d}$ of concentrates $(0.5 \mathrm{~kg}$ of 
Table 1 Feed ingredients, chemical composition and gross energy content of seven diets

\begin{tabular}{|c|c|c|c|c|c|c|c|}
\hline & Reference & Low NDF & High NDF & Low CP & High CP & Low Lipid & High Lipid \\
\hline \multicolumn{8}{|l|}{ Ingredients, g/kg DM } \\
\hline Corn silage & 351 & 430 & - & 375 & 281 & 351 & 351 \\
\hline Alfalfa hay & 89 & 23 & 134 & 66 & 156 & 89 & 89 \\
\hline Ryegrass hay & 47 & - & 231 & 43 & 52 & 47 & 56 \\
\hline Meadow hay & 47 & - & 227 & 47 & 52 & 47 & 60 \\
\hline Corn grain & 205 & 228 & 152 & 258 & 147 & 218 & 160 \\
\hline Barley grain & 119 & 171 & 92 & 160 & 90 & 122 & 100 \\
\hline Soybean meal, (sol. extr., 44) & 113 & 119 & 126 & 27 & 188 & 126 & 18 \\
\hline Whole soybean seeds, cracked & - & - & - & - & - & - & 68 \\
\hline Extruded soybean seeds & - & - & - & - & - & - & 68 \\
\hline Extruded flaxseed seeds & 29 & 29 & 38 & 24 & 34 & - & 29 \\
\hline \multicolumn{8}{|l|}{ Chemical composition, g/kg DM } \\
\hline Crude protein (CP) & 158 & 152 & 161 & 115 & 194 & 161 & 158 \\
\hline Starch & 273 & 273 & 100 & 332 & 176 & 265 & 233 \\
\hline NDF & 361 & 325 & 435 & 358 & 357 & 359 & 360 \\
\hline Hemicellulose & 169 & 171 & 189 & 172 & 158 & 171 & 169 \\
\hline ADF & 192 & 154 & 246 & 186 & 199 & 188 & 191 \\
\hline Cellulose & 163 & 134 & 203 & 160 & 167 & 163 & 163 \\
\hline $\operatorname{Lignin}_{(\mathrm{sa})}$ & 29 & 20 & 43 & 26 & 32 & 25 & 28 \\
\hline $\mathrm{NFC}^{\mathrm{a}}$ & 395 & 443 & 302 & 446 & 357 & 402 & 367 \\
\hline Ether extract & 33 & 34 & 38 & 34 & 34 & 26 & 61 \\
\hline Ash & 53 & 46 & 64 & 47 & 58 & 52 & 54 \\
\hline Gross energy, MJ/kg DM ${ }^{b}$ & 16.8 & 16.9 & 17.3 & 16.8 & 17.3 & 16.5 & 16.7 \\
\hline
\end{tabular}

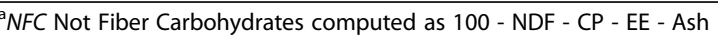

${ }^{\mathrm{b}}$ Measured by a bomb calorimeter method [16]

dry sugar beet pulp, $1 \mathrm{~kg}$ of corn grain, and $1 \mathrm{~kg}$ of sunflower meal). During the collection of rumen fluid, cows were handled according to the Italian law on animal care (Legislative Decree No. 26 of March 14, 2014). Rumen fluid was poured into thermal flasks preheated to $39 \pm$ $0.5^{\circ} \mathrm{C}$, immediately transferred to the laboratory, strained through 3 layers of cheesecloth, to eliminate feed particles, and mixed with buffer solution in a 1 to 2 ratio [17]. Operations were conducted under anaerobic conditions, by flushing with $\mathrm{CO}_{2}$, and required less than $30 \mathrm{~min}$ to be completed. Bottles were placed in a ventilated oven at 39 $\pm 0.4{ }^{\circ} \mathrm{C}$ and automatically vented at a fixed pressure $(6.8$ $\mathrm{kPa})$, to avoid overpressure conditions and alterations of gas and $\mathrm{CH}_{4}$ measures [20]. In vitro GP was monitored in continuous, using a setting of the GP system that allows to record pressure values every minute. Other in vitro parameters (rumen degradability, VFA and $\mathrm{N}-\mathrm{NH}_{3}$ concentrations, $\mathrm{CH}_{4}$ production) were measured only at the end of incubation (at 24 or $48 \mathrm{~h}$ ), to avoid opening of the oven during the incubation, with alteration of fermentation process.

At the end of incubations ( 24 or $48 \mathrm{~h}$ ), two aliquots $(5 \mathrm{~mL})$ of fermentation fluid were collected from each bottle and stored at $-20{ }^{\circ} \mathrm{C}$ with $1 \mathrm{~mL}$ of metaphosphoric acid $(25 \%, w / v)$ to be later analyzed for ammonia $\mathrm{N}$ and volatile fatty acids (VFA). The content of ammonia $\mathrm{N}$ was measured using the FIAstar ${ }^{\mathrm{Tm}} 5000$ Analyzer (FOSS Analytical, Hilleroed, Denmark). The VFA profile was analyzed by GC with flame ionization detection (7820A GC system, Agilent Technologies, Milan, Italy) using a $30-\mathrm{m}$ stainless steel column (J\&W DB-FFAP, Agilent Technologies, Milan, Italy) and $\mathrm{H}_{2}$ as carrier gas (flow rate: $30 \mathrm{~mL} / \mathrm{min}$; isothermal oven temperature: $\left.150{ }^{\circ} \mathrm{C}\right)$. Fermentation fluids were filtered into weighed crucibles $\left(30 \mathrm{~mL}\right.$, Robu Glasfilter-Geräte $\mathrm{GMBH}^{\circ}$, Hattert, Germany) and analyzed for residual NDF using a Fibretech Analyzer (VELP ${ }^{\circ}$ Scientifica, Milan, Italy).

At the end of each incubation ( 24 or $48 \mathrm{~h}$ ), gas was collected with a $10-\mathrm{mL}$ gas-tight syringe (Artsana S.p.A., Como, Italy) from the bottle headspace (HS). At each sampling, the syringe was flushed in order to collect a homogeneous sample, which was immediately transferred into a 9-mL vacuette (Greiner Bio-One $\mathrm{GmbH}$, Kremsmunster, Austria). From each vacuette, an aliquot $(10 \mu \mathrm{L})$ of gas was sampled with a gas-tight syringe 
(1701 N, Hamilton, Bonaduz, Switzerland) and immediately analyzed for $\mathrm{CH}_{4}$ concentration by $\mathrm{GC}$ with flame ionization detection (7820A GC system, Agilent Technologies, Milan, Italy) using a 15-m carbon layer column (GS-CarbonPLOT, Agilent Technologies, Milan, Italy) and $\mathrm{H}_{2}$ as carrier gas (flow rate: $1.6 \mathrm{~mL} / \mathrm{min}$; isothermal oven temperature: $40{ }^{\circ} \mathrm{C}$ ). An 11-point calibration curve was generated from eleven gas mixtures containing 2, 4, $8,16,24,32,60,100,140,180$, and $240 \mathrm{~mL}$ of $\mathrm{CH}_{4} / \mathrm{L}$ (99.5\% pure, SAPIO s.r.l., Monza, Italy), respectively, and known volumes of air. Mixtures were prepared using the same graduated gas-tight syringe (1701 N, Hamilton). The calibration regression had $R^{2}>0.99$.

\section{Computations}

The NDF degradability (NDFd) and the true DM degradability (TDMd) were calculated according to [18].

Recently, [20], using vented bottles connected to tight bags for gas collection, calculated $\mathrm{CH}_{4}$ production $(\mathrm{mL})$ as: $\left[\mathrm{CH}_{4}\right.$ concentration in $\left.\mathrm{HS}\right] \times[\mathrm{HS}$ volume $]+\left[\mathrm{CH}_{4}\right.$ concentration in the gas bag $\times \mathrm{GP}]$. To evaluate the possibility of avoiding the use of bags, to save space and increase the number of replicates, amount of $\mathrm{CH}_{4}$ lost with gas venting was computed using the unpublished data of a previous study, where 4 forages and 3 concentrates were incubated in 42 bottles ( 6 bottles/feed) for 6 , 24 , or $48 \mathrm{~h}$ using the same GP equipment and the same operative conditions of the present experiment. It was found that total $\mathrm{CH}_{4}$ production is predictable, with acceptable precision and accuracy, as: $-0.0064 \times\left[\mathrm{CH}_{4}\right.$ concentration in $\mathrm{HS} \times(\mathrm{HS}$ volume $+\mathrm{GP})]^{2}+0.9835 \times\left[\mathrm{CH}_{4}\right.$ concentration in $\mathrm{HS} \times(\mathrm{HS}$ volume $+\mathrm{GP})]$. This equation had a residual standard deviation of only $0.1770 \mathrm{~mL}$, and $\mathrm{R}^{2}=0.9993$. Thus, the present experiment was conducted without the use of tight bags for gas collection. The $\mathrm{CH}_{4}$ production was computed using the above described equation and it was expressed as $\mathrm{mL} / \mathrm{g} \mathrm{DM}$ incubated, $\mathrm{mL} / \mathrm{g}$ of digested NDF (dNDF), $\mathrm{mL} / \mathrm{g}$ TDMd, or $\mathrm{mL} /$ $100 \mathrm{~mL}$ GP. In vitro GP and $\mathrm{CH}_{4}$ were also predicted from VFA production, according to [21].

\section{Statistical analysis}

The mean of the 5 replications for each diet in each incubation run was computed. These 28 means were analyzed using PROC MIXED of SAS [22] using a model considering the diet (D; $6 \mathrm{df})$, the incubation time (IT, $1 \mathrm{df})$, and the interaction diet $x$ incubation time as fixed factors, the run within incubation time ( $2 \mathrm{df}$ ) as a random blocking factor and the residual error term $e(18 \mathrm{df})$. As the diet $x$ incubation time interaction was never significant, it was excluded from the model. Contrasts were run to analyze statistical differences among diets with different contents of a given chemical constituent, using the Bonferroni adjustment to perform multiple comparisons.

\section{Results}

Changes of the feed ingredients proportions and of dietary contents of chemical constituents had influence on the various parameters of in vitro fermentation (Table 2). As expected, $\mathrm{pH}$ values measured at the end of fermentation were not influenced by the dietary changes. The ammonia $\mathrm{N}$ content increased with increasing dietary $\mathrm{CP}$ content $(P=0.014)$. No influence of the diets was observed on the VFA production, but the proportion of acetate or butyrate decreased $(P<0.001)$ or increased $(P=0.004)$, respectively, with a decrease of NDF content, whereas the proportion of propionate decreased $(P=0.048)$ with increasing dietary $\mathrm{CP}$. Thus, the ratio between acetate and propionate decreased with decreasing level of NDF $(P=0.001)$ and of CP $(P<0.001)$, and the corresponding increasing level of starch. Increasing proportions of dietary $\mathrm{CP}$ increased the proportion of other VFA $(P<0.001)$ found in the rumen fluid. Changes of dietary EE content had no consequence on the various rumen fluid parameters. The prolongation of the incubation time from 24 to $48 \mathrm{~h}$ increased the VFA production $(P=0.029)$, but it did not influence $\mathrm{pH}$ and ammonia $\mathrm{N}$ values.

The NDFd, TDMd, and the GP expressed per unit of incubated DM or per unit of TDMd (Table 3) increased with a decrease of NDF content $(P<0.001$ for all). When the NDF content decreased, the $\mathrm{CH}_{4}$ production increased per unit of incubated DM $(P<0.001)$ and per $g$ of digested NDF $(P=0.002)$, but not per unit of TDMd. The increased dietary $\mathrm{CP}$ content, with the corresponding decrease of starch, had no influence on NDFd or TDMd, but GP was lowered. No influence was observed on the production of $\mathrm{CH}_{4}$, except when this was expressed as a proportion of $\mathrm{GP}\left(\mathrm{mL} \mathrm{CH}_{4} / 100 \mathrm{~mL} \mathrm{GP} ; \mathrm{P}<0.001\right)$. An increased inclusion of extruded oilseeds in the diet reduced both NDFd $(P=0.003)$ and TDMd $(P=0.028)$, and the measured GP expressed per g of incubated DM $(P=0.017)$, but no influences were observed on the $\mathrm{CH}_{4}$ yield. A prolonged duration of the incubation, from 24 to $48 \mathrm{~h}$, increased NDFd $(P=0.009)$, TDMd $(P=0.007)$, and $\mathrm{CH}_{4}$ production, both per unit of incubated DM $(P=0.014)$ and per unit of TDMd $(P=0.027)$. The correlation between measured and predicted values showed $\mathrm{R}^{2}$ to be 0.78 and 0.74 , respectively, for gas and $\mathrm{CH}_{4}$ measures (data not shown), and the relationship obtained by regressing measured values of $\mathrm{CH}_{4}$ (mL/g DM; y) against those predicted (mL/g DM; x) was the following: measured $\mathrm{CH}_{4}=0.95 \times$ predicted $\mathrm{CH}_{4}-2.6$. Predicted values of GP and $\mathrm{CH}_{4}$ productions were not influenced either by dietary changes or by incubation time.

\section{Discussion}

General considerations

The diets were formulated using feed ingredients commonly used in the Po valley (North-East of Italy) and 
Table 2 Effect of diets and incubation time on $\mathrm{pH}$, ammonia N concentration, volatile fatty acid production (VFA) and molar proportions of acetate, propionate, butyrate and other VFA

\begin{tabular}{|c|c|c|c|c|c|c|c|c|}
\hline & $\mathrm{pH}$ & Ammonia $\mathrm{N}, \mathrm{mg} / \mathrm{L}$ & VFA, mmoL/L & Acetate (Ac), \% VFA & Propionate (Pr), \% VFA & Ac:Pr & Butyrate, \% VFA & Other VFA, \% VFA \\
\hline \multicolumn{9}{|l|}{ Diet } \\
\hline Reference & 6.87 & 202 & 5.08 & 56.1 & 23.5 & 2.40 & 16.0 & 4.47 \\
\hline Low NDF & 6.88 & 192 & 5.37 & 55.8 & 23.7 & 2.36 & 16.2 & 4.29 \\
\hline High NDF & 6.90 & $223^{A}$ & 4.44 & $58.5^{\mathrm{A}}$ & 23.1 & 2.53 & $13.3^{\mathrm{B}}$ & $4.26^{\mathrm{B}}$ \\
\hline Low CP & 6.85 & 171 & 5.06 & 56.0 & 24.3 & 2.31 & 16.1 & $3.71^{\mathrm{B}}$ \\
\hline High CP & 6.87 & $222^{\mathrm{A}}$ & 4.89 & 57.2 & 22.8 & 2.51 & 14.6 & $4.85^{\mathrm{A}}$ \\
\hline Low lipid & 6.87 & 207 & 4.96 & 56.4 & 23.7 & 2.39 & 15.5 & $4.26^{\mathrm{B}}$ \\
\hline High lipid & 6.90 & 197 & 4.99 & 56.7 & 23.5 & 2.41 & 15.4 & 4.36 \\
\hline SEM & 0.043 & 28.5 & 0.231 & 0.25 & 0.64 & 0.062 & 0.91 & 0.158 \\
\hline$P$-value & 0.46 & 0.008 & 0.25 & $<0.001$ & 0.06 & 0.001 & 0.002 & $<0.001$ \\
\hline \multicolumn{9}{|l|}{$P$-value of contrasts } \\
\hline Low vs High NDF & 0.99 & 0.44 & 0.23 & $<0.001$ & 0.99 & 0.001 & 0.004 & 0.99 \\
\hline Low vs High CP & 0.99 & 0.014 & 0.99 & 0.048 & 0.048 & $<0.001$ & 0.99 & $<0.001$ \\
\hline Low vs High lipid & 0.99 & 0.99 & 0.99 & 0.99 & 0.99 & 0.65 & 0.99 & 0.99 \\
\hline \multicolumn{9}{|l|}{ Incubation time } \\
\hline $24 \mathrm{~h}$ & 6.95 & 202 & 4.47 & 57.2 & 22.9 & 2.50 & 15.8 & 3.87 \\
\hline $48 \mathrm{~h}$ & 6.80 & 202 & 5.47 & 56.1 & 24.1 & 2.33 & 14.7 & 4.76 \\
\hline SEM & 0.055 & 38.7 & 0.123 & 0.13 & 0.82 & 0.077 & 1.15 & 0.201 \\
\hline$P$-value & 0.31 & 0.99 & 0.029 & 0.026 & 0.39 & 0.26 & 0.58 & 0.09 \\
\hline RMSE & 0.032 & 17.5 & 0.462 & 0.49 & 0.60 & 0.112 & 0.87 & 0.147 \\
\hline
\end{tabular}

Values with different superscripts within column are significantly $(P<0.05)$ higher (A) or lower (B) compared to the reference diet (containing 361,158 , and $33 \mathrm{~g} / \mathrm{kg}$ DM of NDF, CP, and lipids)

Low NDF low NDF diet (325 g/kg DM); High NDF high NDF diet (435 g/kg DM), Low CP low protein diet (CP, $115 \mathrm{~g} / \mathrm{kg} \mathrm{DM),} \mathrm{High} \mathrm{CP} \mathrm{high} \mathrm{protein} \mathrm{diet} \mathrm{(CP,} 194 \mathrm{~g} / \mathrm{kg}$ $\mathrm{DM})$, Low lipid low lipid diet (EE, $26 \mathrm{~g} / \mathrm{kg} \mathrm{DM})$, High lipid high lipid diet (EE, $61 \mathrm{~g} / \mathrm{kg} \mathrm{DM})$

composed mainly by cereal grains, corn silage and various hays. It should be preliminarily considered that in this study the variation in the content of the various nutrients, namely, NDF, CP and lipid, were always achieved by decreasing or increasing the proportion of dietary starch. In the scientific literature, in vitro evaluation of gas and $\mathrm{CH}_{4}$ productions is commonly carried out using single feeds, mainly forages, whereas less information is available for complete diets [23]. In vivo measurement of gas and $\mathrm{CH}_{4}$ production requires expensive equipment and it is labor and time consuming. In vitro techniques would permit a much more simple determination of the dietary characteristics which can influence the potential emission of gas and $\mathrm{CH}_{4}$ from their fermentation in a simulated rumen environment [20]. Studies of the relationships between in vitro and in vivo gas and $\mathrm{CH}_{4}$ productions are lacking [23]. However, a recent study suggested that in vitro gas and $\mathrm{CH}_{4}$ measurements can be indicative of the trend of in vivo $\mathrm{CH}_{4}$ production originating from different combinations of feed ingredients [24]. This study was aimed at evaluating if changes in the diet composition might or might not have notable influence on gas and $\mathrm{CH}_{4}$ productions.
After $24 \mathrm{~h}$ of fermentation, the measured GP of the various diets was, on average, $250 \mathrm{~mL} / \mathrm{g} \mathrm{DM}$, suggesting that a cow consuming $20 \mathrm{~kg} / \mathrm{d}$ DM might produce about $5,000 \mathrm{~L} / \mathrm{d}$ of gas. The $\mathrm{CH}_{4}$ production from fermentation of these diets ranged 30.8 to $34.4 \mathrm{~mL} / \mathrm{g} \mathrm{DM}$, suggesting that, for a DM intake of $20 \mathrm{~kg} / \mathrm{d}$, a cow might produce 616 to $688 \mathrm{~L} / \mathrm{d}$ of $\mathrm{CH}_{4}$. Sauer et al. (1998) reported in vivo $\mathrm{CH}_{4}$ production of lactating cows in the order of $622 \mathrm{~L} / \mathrm{d}$, corresponding to $38.9 \mathrm{~mL} / \mathrm{g} \mathrm{DM}$ intake. In the study of [25], $\mathrm{CH}_{4}$ production from dairy cows was $29.2 \mathrm{~mL} / \mathrm{g}$ DM intake, whereas [26] reported for sheep an averaged $\mathrm{CH}_{4}$ production of $31.0 \mathrm{~mL} / \mathrm{g}$ DM intake. In a continuous culture fermenter, [27] measured an averaged $\mathrm{CH}_{4}$ production of $33.0 \mathrm{~mL} / \mathrm{g} \mathrm{DM}$. The in vitro $\mathrm{CH}_{4}$. production of the dairy rations tested by [23] varied from 30.1 to $35.9 \mathrm{~mL} / \mathrm{g} \mathrm{DM}$, a range consistent with results obtained in this study. However, comparison with data from literature is difficult because huge variations in gas and $\mathrm{CH}_{4}$ productions are commonly observed across experiments, even for diets with similar composition. This is the consequence of a combination of different biological, as rumen fluid characteristics, and technical factors, as fermentation procedures and 
Table 3 Effects of diets and incubation time on in vitro degradability of NDF (NDFd) and of true DM (TDMd), gas production (GP) and methane $\left(\mathrm{CH}_{4}\right)$ production, and predicted values of GP and $\mathrm{CH}_{4}$ production

\begin{tabular}{|c|c|c|c|c|c|c|c|c|c|c|}
\hline & \multicolumn{2}{|l|}{ Degradability } & \multicolumn{3}{|c|}{ Actual GP, ml per: } & \multicolumn{3}{|c|}{ Actual $\mathrm{CH}_{4} \mathrm{~mL}$ per } & \multirow{2}{*}{$\begin{array}{l}\text { Predicted GP } \\
\mathrm{mL} / \mathrm{g} \text { DM }\end{array}$} & \multirow{2}{*}{$\begin{array}{l}\text { Predicted } \mathrm{CH}_{4} \\
\mathrm{~mL} / \mathrm{g} \mathrm{DM}\end{array}$} \\
\hline & NDFd, $\mathrm{g} / \mathrm{kg}$ NDF & TDMd, g/kg DM & g DM & g TDMd & g DM & $\mathrm{gdNDF}$ & g TDMd & $100 \mathrm{~mL} \mathrm{GP}$ & & \\
\hline \multicolumn{11}{|l|}{ Diet } \\
\hline Reference & 567 & 840 & 274 & 325 & 34.2 & 168 & 40.8 & 12.5 & 244 & 38.8 \\
\hline Low NDF & $612^{\mathrm{A}}$ & $872^{\mathrm{A}}$ & $288^{\mathrm{A}}$ & 331 & 34.4 & 174 & 39.3 & 11.9 & 250 & 39.6 \\
\hline High NDF & $480^{B}$ & $767^{B}$ & $228^{\mathrm{B}}$ & $300^{B}$ & $30.8^{B}$ & $151^{B}$ & 39.9 & $13.5^{\mathrm{A}}$ & 220 & 35.9 \\
\hline Low CP & 545 & 835 & 277 & 333 & 33.4 & 169 & 39.9 & 12.0 & 242 & 38.0 \\
\hline High CP & 542 & 831 & $255^{B}$ & 310 & 34.0 & 176 & 41.0 & $13.3^{\mathrm{A}}$ & 234 & 37.8 \\
\hline Low lipid & 583 & 845 & 265 & 315 & 33.1 & 159 & 39.0 & 12.3 & 251 & 37.2 \\
\hline High lipid & 531 & 826 & $253^{B}$ & $304^{B}$ & $32.2^{B}$ & 169 & 38.8 & 12.5 & 238 & 37.9 \\
\hline SEM & 10.3 & 4.2 & 5.6 & 7.2 & 0.53 & 3.4 & 0.63 & 0.40 & 10.9 & 2.09 \\
\hline$P$-value & $<0.001$ & $<0.001$ & $<0.001$ & $<0.001$ & $<0.001$ & $<0.001$ & 0.025 & $<0.001$ & 0.33 & 0.70 \\
\hline \multicolumn{11}{|l|}{$P$-value of contrasts } \\
\hline Low vs High NDF & $<0.001$ & $<0.001$ & $<0.001$ & $<0.001$ & $<0.001$ & 0.002 & 0.99 & $<0.001$ & 0.99 & 0.99 \\
\hline Low vs High CP & 0.99 & 0.99 & $<0.001$ & 0.009 & 0.99 & 0.99 & 0.99 & $<0.001$ & 0.99 & 0.99 \\
\hline Low vs High lipid & 0.003 & 0.028 & 0.017 & 0.99 & 0.99 & 0.99 & 0.99 & 0.99 & 0.99 & 0.99 \\
\hline \multicolumn{11}{|l|}{ Incubation time } \\
\hline $24 \mathrm{~h}$ & 472 & 801 & 250 & 314 & 29.6 & 172 & 37.0 & 11.9 & 214 & 34.9 \\
\hline $48 \mathrm{~h}$ & 631 & 860 & 276 & 320 & 36.7 & 161 & 42.6 & 13.2 & 260 & 41.5 \\
\hline SEM & 10.5 & 3.5 & 7.4 & 8.8 & 0.59 & 1.8 & 0.66 & 0.54 & 7.6 & 1.69 \\
\hline$P$-value & 0.009 & 0.007 & 0.14 & 0.69 & 0.014 & 0.046 & 0.027 & 0.22 & 0.06 & 0.12 \\
\hline RMSE & 15.5 & 7.2 & 4.0 & 7.6 & 0.69 & 3.2 & 0.94 & 0.25 & 21.9 & 3.78 \\
\hline
\end{tabular}

Values with different superscripts within column are significantly $(P<0.05)$ higher $(A)$ or lower $(B)$ compared to the reference diet (containing 361, 158, and 33 g/kg DM of NDF, CP, and lipids)

Low NDF low NDF diet (325 g/kg DM), High NDF high NDF diet (435 g/kg DM), Low CP low protein diet (CP, $115 \mathrm{~g} / \mathrm{kg} \mathrm{DM),} \mathrm{High} \mathrm{CP} \mathrm{high} \mathrm{protein} \mathrm{diet} \mathrm{(CP,} 194 \mathrm{~g} / \mathrm{kg}$ $\mathrm{DM})$, Low lipid low lipid diet (EE, $26 \mathrm{~g} / \mathrm{kg} \mathrm{DM})$, High lipid high lipid diet (EE, $61 \mathrm{~g} / \mathrm{kg} \mathrm{DM})$

equipment for collection, measurement and analysis [28]. In this experiment the observed GP and $\mathrm{CH}_{4}$ were regressed against the GP and $\mathrm{CH}_{4}$ values predicted from the stoichiometry of the VFA production, to obtain an internal control of consistency of the data. The correlations found $\left(R^{2}=0.78\right.$ and 0.74 , respectively, for gas and $\mathrm{CH}_{4}$ measures) are acceptable considering the rather narrow range of variation in GP and $\mathrm{CH}_{4}$ production caused by the dietary changes. It was observed that the SEM of predicted GP and $\mathrm{CH}_{4}$ production (21.9 and $3.78 \mathrm{~mL} / \mathrm{g} \mathrm{DM}$, respectively) was about five times greater than the corresponding values of the measured GP and $\mathrm{CH}_{4}$ production. In other words, the measure of the VFA production was less precise than the $\mathrm{GP}$ and $\mathrm{CH}_{4}$ measures.

\section{Effects on NDF degradability, gas and $\mathrm{CH}_{4}$ production due to changes in the NDF content}

In this experiment, the diet with the low level of NDF $(325 \mathrm{~g} / \mathrm{kg}$ DM) was based on corn silage and a small amount of alfalfa hay (23 g/ $\mathrm{kg} \mathrm{DM})$ as forage sources.
On the contrary, the diet with the high level of NDF (435 g/kg DM) was based on different hays and did not contain corn silage. This is of interest in Italy as use of silages for the production of important Protected Denomination of Origin (PDO) cheeses (i.e., ParmigianoReggiano) is forbidden by specific feeding regulations. From the results it emerged that NDF degradability was negatively influenced by the dietary NDF content, partially because of the complete replacement of corn silage with hays. This would be in agreement with previous observations that the NDF fraction of hay samples collected in the same area of the present experiment were less degradable than corn silage samples [19].

In diets similar for ingredient composition to those used in this experiment, [12] observed an increased $\mathrm{CH}_{4}$ production (35.6 to $44.3 \mathrm{~mL} / \mathrm{g} \mathrm{DM}$ ) with decreasing NDF content. In the present study, a decrease from 435 to $325 \mathrm{~g} \mathrm{NDF} / \mathrm{kg} \mathrm{DM}$ increased $\mathrm{CH}_{4}$ production from 30.8 to $34.4 \mathrm{~mL} / \mathrm{g} \mathrm{DM}(+11.6 \%)$. This is consistent with an increased true degradability of the feed $(+14 \%)$, but also of the NDF fibrous fraction (+27 \%). This seems to 
be contradictory with current literature, as a decrease of dietary NDF commonly reduces the NDF degradability [12]. However, also [29] evidenced that a decrease of the dietary NDF content increased by $43 \%$ in vivo $\mathrm{CH}_{4}$ production expressed per unit of dNDF. Results also evidenced that GP increased with a decrease of NDF content even when expressed per unit of TDMd (+10\%), but no influences were observed on the $\mathrm{CH}_{4}$ production per unit of TDMd. A different trend emerged when $\mathrm{CH}_{4}$ production was referred to the total GP. In this case, the decrease of NDF lowered the $\mathrm{CH}_{4}$ proportion by about $12 \%$ (13.5 to $11.9 \mathrm{~mL} \mathrm{CH}_{4} / 100 \mathrm{~mL} \mathrm{GP}$, for the high and the low content of NDF, respectively). Results suggest that a decrease of dietary NDF content, achieved from a complete replacement of hays with corn silage and cereal grains, might increase feed digestibility without changing GP and $\mathrm{CH}_{4}$ produced per unit of digested material.

\section{Effects on gas and $\mathrm{CH}_{4}$ production due to changes in the $\mathrm{CP}$ content}

In this experiment an increased proportion of $\mathrm{CP}$, in replacement of starch, caused a reduction of GP. The negative influence of dietary CP on GP has been observed by others in the past. Such an effect was attributed to the buffer capacity of $\mathrm{CP}$, that reduces the indirect $\mathrm{CO}_{2}$ released from the buffered rumen fluid, and to the stoichiometry of protein fermentation, that differs from that of carbohydrates [30, 31]. In this study, increase of the $\mathrm{CP}$ content was associated to a decrease of dietary starch. As a consequence, some VFA as iso-butyric and iso-valeric acids were increased, being end-products of protein degradation [32], whereas the production of propionate decreased and the ratio between acetate and propionate increased. Changes in the dietary CP proportion had no effect on $\mathrm{CH}_{4}$ production when expressed both per unit of incubated DM and per unit of TDMd. Thus, as CP depresses GP, an increased proportion of $\mathrm{CP}$ increases the $\mathrm{CH}_{4}$ concentration on total GP.

\section{Effects on gas and $\mathrm{CH}_{4}$ production due to changes in the lipid content}

In this experiment changes in the dietary fat content of the diets were achieved by changing the proportions of extruded flaxseeds, extruded soybean and whole soybean seeds. The threshold of $60 \mathrm{~g}$ fat $/ \mathrm{kg} \mathrm{DM}$ was considered to be the upper limit to avoid a possible impairment of feed digestibility $[6,33]$.

The effect of dietary lipids on $\mathrm{CH}_{4}$ production is dependent on the source, FA profile, level of inclusion, and diet composition [34]. The level of supplementation and the physical form of the lipid supplement affect its availability in the rumen, and these factors appear to be more important than the FA profile [35]. In this regard, [36], using dairy cows housed in respiratory chambers, found that, compared to the control, the average reduction in $\mathrm{CH}_{4}(\mathrm{~L} / \mathrm{kg} \mathrm{DMI})$ per $10 \mathrm{~g} / \mathrm{kg}$ of crude fat added was persistent throughout lactation. The same authors observed that the most effective lipid source in reducing methanogenesis was a commercial vegetal rumen protected fat fortified with hydroxymethionine-analog-isobutyrate $\left(-5.5 \%\right.$ of $\left.\mathrm{CH}_{4}\right)$, followed by vegetal rumen protected fat $(-2.3 \%)$, and by whole cracked rapeseed $(-0.8 \%)$. In the experiment of [35], only crushed canola seeds lowered $\mathrm{CH}_{4}$ production per unit of digestible DM intake (-15\%), whereas crushed flaxseeds and crushed sunflower seeds did not reduce $\mathrm{CH}_{4}$ production compared to the control diet (a diet supplemented with a commercial source of calcium salts of long chain fatty acids). In the current experiment, fat addition reduced feed degradability, particularly that of the NDF fraction. No influences were found on total VFA production and on the proportion of acetate, propionate and butyrate, whereas GP and $\mathrm{CH}_{4}$ productions decreased by 8 and $6 \%$, respectively, compared to the reference diet. However, differences were greatly reduced when GP and $\mathrm{CH}_{4}$ were expressed per unit of TDMd suggesting that, under the commercial conditions evaluated in this study, small reductions of $\mathrm{CH}_{4}$ might be achieved.

\section{Conclusions}

Changes of the ingredient and chemical composition of diets were analyzed to evaluate benefits in the amount of $\mathrm{CH}_{4}$ produced, for the north eastern Italian dairy production chain. It was found that a replacement of hays with corn silage and cereals might increase GP and $\mathrm{CH}_{4}$ per unit of DM intake. An increase of the dietary CP content would reduce GP with no influences in the amount of $\mathrm{CH}_{4}$ produced, whereas a moderate addition of cracked soybean seeds, and extruded flaxseed had few, or any, influence on the in vitro GP and $\mathrm{CH}_{4}$ productions. In general, none of the various strategies tested in the present work was able to reduce the amount of $\mathrm{CH}_{4}$ produced, especially if this production is expressed per unit of digestible DM intake. More research is needed to evaluate the effectiveness of strategies to reduce the $\mathrm{CH}_{4}$ emissions, and relationships between in vitro and in vivo gas and $\mathrm{CH}_{4}$ productions need to be developed.

\section{Abbreviations}

ADF, Acid detergent fibre expressed inclusive of residual ash; $C P$, Crude protein; DM, Dry matter; EE, Ether extract; GP, Gas production; NDF, Neutral detergent fibre assayed with a heat stable amylase and expressed inclusive of residual ash; NDFd, NDF degradability; lignin(sa), Lignin determined by solubilization of cellulose with sulphuric acid; NRC, National Research Council; RMSE, Root mean square error; SEM, Standard error of the mean; TDMd, True DM degradability; VFA, Volatile fatty acids 


\section{Acknowledgments}

This work was financed by the project "ARCHAEA - Feeding strategies to reduce methane emissions from dairy cows" - Veneto Region Rural Development Programme (RDP) 2007-2013.

\section{Authors' contributions}

All authors conceived of this experiment, due to experience gained over the last years in the use of in vitro gas production technique for the evaluation of ruminant feeds. LM and MC gave substantial contributions to analytical procedures, statistical analysis, and writing of the manuscript. FT, LB, and SS contributed in revising critically the manuscript. All authors read and approved the final manuscript.

\section{Competing interests}

The authors declare that they have no competing interests.

\section{Author details}

'Department of Comparative Biomedicine and Food Science (BCA), University of Padova, Viale dell'Università 16, 35020 Legnaro (PD), Italy. ${ }^{2}$ Department of Agronomy, Food, Natural resources, Animals and Environment (DAFNAE), University of Padova, Viale dell'Università 16, 35020 Legnaro (PD), Italy.

Received: 14 January 2016 Accepted: 17 August 2016

\section{Published online: 17 September 2016}

\section{References}

1. Cottle DJ, Nolan JV, Wiedemann SG. Ruminant enteric methane mitigation: a review. Anim Prod Sci. 2011:51(6):491-514.

2. Ellis JL, Kebreab E, Odongo NE, McBride BW, Okine EK, France J. Prediction of methane production from dairy and beef cattle. J Dairy Sci. 2007;90(7): $3456-466$.

3. Grainger C, Beauchemin KA. Can enteric methane emissions from ruminants be lowered without lowering their production? Anim Feed Sci Technol. 2011:166-167:308-20.

4. Johnson KA, Johnson DE. Methane emissions from cattle. J Anim Sci. 1995; 73(8):2483-92.

5. Patra AK. Enteric methane mitigation technologies for ruminant livestock: a synthesis of current research and future directions. Environ Monit Assess. 2012;184(4):1929-952.

6. Kumar S, Choudhury PK, Carro MD, Griffith GW, Dagar SS, Puniya M, et al. New aspects and strategies for methane mitigation fromruminants. Appl Microbiol Biotechnol. 2014;98(1):31-44.

7. Bannink A, Dijkstra J, Mills JAN, Kebreab E, France J. Nutritional strategies to reduce enteric methane formation in dairy cows. In: Emissions from European Agriculture. 2005. p. 367-76.

8. Yan T, Frost JP, Keaty TWJ, Agnew RE, Mayne CS. Prediction of nitrogen excretion in feces and urine of beef cattle offered diets containing grass silage. J Anim Sci. 2007:85(8):1982-989.

9. Schiavon S, Cesaro G, Tagliapietra F, Gallo L, Bittante G. Influence of N shortage and conjugated linoleic acid supplementation on some productive, digestive, and metabolic parameters of lactating cows. Anim Feed Sci Technol. 2015:208:86-97.

10. Dijkstra J, Oenema O, Bannink A. Dietary strategies to reducing N excretion from cattle: implications for methane emissions. Curr Opin Environ Sustain. 2011;3(5):414-22

11. Dal Maso M, Tagliapietra F, Cattani M, Fracasso A, Miotello S, Schiavon S. Characteristics of dairy farms in the North-Eastern part of Italy: rations, milk yield and nutrients excretion. Ital J Anim Sci. 2009:8(2):295-97.

12. Pirondini M, Malagutti L, Colombini S, Amodeo P, Crovetto GM. Methane yield from dry and lactating cows diets in the Po Plain (Italy) using an in vitro gas production technique. Ital J Anim Sci. 2012;11(3):330-35.

13. International AOAC. Official Methods of Analysis. 19th ed. Gaithersburg: AOAC International; 2012

14. Robertson JB, Van Soest PJ. The detergent system of analysis and its application to human foods. In: James WPT, Theander O, editors. The Analysis of Dietary Fiber in Food. New York: Marcel Dekker Inc; 1981. p. 123-58.

15. Bouchard J, Chornet E, Overend RP. High-performance liquid chromatographic monitoring carbohydrate fractions in partially hydrolyzed corn starch. J Agric Food Chem. 1988;36(6):1188-192.
16. ISO 9831. Animal feeding stuffs, animal products, and faeces or urine Determination of gross calorific value - Bomb calorimeter method. Geneva: ISO 9831; 1988.

17. Menke $\mathrm{KH}$, Steingass $\mathrm{H}$. Estimation of the energetic feed value obtained from chemical analysis and gas production using rumen fluid. Anim Res Dev. 1988:28:7-55.

18. Goering HK, Van Soest PJ. Forage fiber analysis (apparatus, reagents, procedures, and some applications). Agricultural hand-book no. 379 Washington, DC: USDA; 1970.

19. Tagliapietra F, Cattani M, Hindrichsen IK, Hansen HH, Colombini S, Bailoni L, et al. True dry matter digestibility of feeds evaluated in situ with different bags and in vitro using rumen fluid collected from intact donor cows. Anim Prod Sci. 2012:52(5):338-346.

20. Cattani M, Tagliapietra F, Maccarana L, Hansen HH, Bailoni L, Schiavon S. Technical note: In vitro total gas and methane production measurements from closed or vented rumen batch culture systems. J Dairy Sci. 2014;97(3): 1736-741.

21. Blümmel M, Aiple KP, Steingass $H$, Becker K. A note on the stoichiometrical relationship of short chain fatty acid production and gas formation in vitro in feedstuffs of widely differing quality. J Anim Physiol Anim Nutr. 1999; 81(3):157-67.

22 Institute SAS. SAS User's Guide: Basics. Cary: SAS Inst. Inc.: 2007.

23. Getachew G, Robinson PH, Depeters EJ, Taylor SJ, Gisi DD, Higginbotham $\mathrm{GE}$, Riordan TJ. Methane production from commercial dairy rations estimated using an in vitro gas technique. Anim Feed Sci Technol. 2005; 123-124(1):391-402

24. Hatew B, Cone JW, Pellikaan WF, Podesta SC, Bannink A, Hendriks WA, et al. Relationship between in vitro and in vivo methane production measured simultaneously with different starch sources and starch levels in dairy cattle. Anim Feed Sci Technol. 2015;202:20-31.

25. Holter JB, Young AJ. Methane production in dry and lactating cows. J Dairy Sci. 1992;75(8):2165-175.

26. Moss AR. Environmental control of methane production by ruminants. In: Young BA, editor. Greenhouse gases and animal agriculture, Takahashi, J. Amsterdam, The Netherlands: Elsevier; 2002. p. 67-76.

27. Eun JS, Fellner V, Gumpertz ML. Methane production by mixed ruminal cultures incubated in dual-flow fermenters. J Dairy Sci. 2004:87(1):112-21.

28. Maccarana L, Cattani M, Mantovani R, Tagliapietra F, Schiavon S, Bailoni L. Assessment of factors influencing in vitro gas and methane production by meta-analysis. Milan: Proceedings of the 21st ASPA Congress; 2015. p. 22.

29. Pirondini M, Colombini S, Mele M, Malagutti L, Rapetti L, Galassi G, et al. Effects of dietary starch concentration and fish oil supplementation on milk yield and composition, diet digestibility, and methane emissions in lactating dairy cows. J Dairy Sci. 2015:98(1):357-372.

30. Cone JW, Van Gelder AH. Influence of protein fermentation on gas production profiles. Anim Feed Sci Technol. 1999:76:251-164.

31. Tagliapietra F, Cattani M, Hansen HH, Hindrichsen IK, Bailoni L, Schiavon S. Metabolizable energy content of feeds based on 24 or $48 \mathrm{~h}$ in situ NDF digestibility and on in vitro $24 \mathrm{~h}$ gas production methods. Anim Feed Sci Technol. 2011:170:182-91.

32. Hungate RE. The rumen and its microbes. New York: New York Academic Press; 1966.

33. Jenkins T. Success of fat in dairy rations depends on the amount. Feedstuffs. 1997;69:11-12

34. Knapp JR, Laur GL, Vadas PA, Weiss WP, Tricarico JM. Invited review: enteric methane in dairy cattle production: quantifying the opportunities and impact of reducing emissions. J Dairy Sci. 2014;97(6):3231-261.

35. Beauchemin KA, McGinn SM, Benchaar C, Holtshausen L. Crushed sunflower flax, or canola seeds in lactating dairy cow diets: Effects on methane production, rumen fermentation, and milk production. J Dairy Sci. 2009; 92(5):2118-127.

36. Alstrup L, Frydendahl Hellwing AL, Lund P, Weisbjerg MR. Effect of fat supplementation and stage of lactation on methane production in dairy cows. Anim Feed Sci Technol. 2015:207:10-19. 